\title{
An assessment of the influence of silver stabilized hydrogen peroxide on the eggshell condition
}

\author{
Łukasz Tomczyk ${ }^{1 \star}$, Tomasz Szablewski ${ }^{1}$, Renata Cegielska-Radziejewska', Lidia Lewko², Piotr Konieczny ${ }^{1}$ \\ ${ }^{1}$ Department of Food Quality Management, Poznań University of Life Sciences, ul. Wojska Polskiego 71, 60-625 Poznań, Poland, ${ }^{2}$ National \\ Research Institute of Animal Production, Department of Animal Genetic Resources Conservation, Zakrzewo, ul. Poznańska 18, 62-070 \\ Dopiewo, Poland
}

\section{A B S T R A C T}

\begin{abstract}
The aim of the study was to assess the condition of eggshells hygienised with an silver stabilized hydrogen peroxide of different concentrations. Eggs were treated with a solution of the preparation and stored for four weeks. In preliminary investigations the elastic deformation of eggshells was measured and analysed in order to determine the influence of a preparation concentrated at $0.01-3 \%$ on the eggshell strength. The research proved that a preparation concentrated at $1-3 \%$ significantly reduced the eggshell strength. At the next stage of the research, having excluded the high concentrations with a negative effect on eggshell strength, i.e. 1-3\%, the experiment was conducted again. It was followed by a microbiological analysis in which the total count of aerobic bacteria, yeasts, moulds ad also bacteria from the Pseudomonas genus and Enterobacteriaceae family were measured. The investigations confirmed that the preparation concentrated at $0.01-0.9 \%$ did not have a significant influence on eggshell strength. Hygienisation in solutions concentrated at $0.01-$ $0.9 \%$ caused complete inactivation of bacteria of the Enterobacteriaceae family, yeasts and moulds. Immediately after treatment with the preparation concentrated at $0.3 \%$ the count of aerobic bacteria and the bacteria of the Pseudomonas genus decreased by 1.9 log $\mathrm{CFU} / \mathrm{g}$ and $0.7 \mathrm{log} \mathrm{CFU} / \mathrm{g}$, respectively. The hygienisation of eggs with the preparation concentrated at $0.9 \%$ and storing them for four weeks under controlled conditions reduced the count of aerobic bacteria by 1.9 log and the count of Pseudomonas bacteria by 1.7 log, as compared with the reference sample.
\end{abstract}

Keywords: Silver ions; Hydrogen peroxide; Eggs; Eggshell strength; Microbiological quality

\section{INTRODUCTION}

Due to the high consumption of eggs in recent years, producers have been obliged to guarantee adequate quality of their products. The quality of eggs is determined by a set of traits, such as their size, weight, shape (Haugh unit > 75), appearance (clean and undamaged shell), nutritional value, safety (absence of pathogenic microorganisms, toxins and heavy metals). Other important factors are the health of egg-laying hens and the conditions of egg acquisition, storage and distribution.

The environmental conditions of a henhouse significantly determine the microbiological state of eggs. Inappropriate storage and distribution conditions may accelerate the development of microflora. During storage the microflora on the eggshell surface may penetrate through pores into the egg content (Baron, 2007; Szablewski et al., 2010b).
The presence of microorganisms results in changes in the colour of the egg white or yolk (Psendomonas, Aeromonas, Enterobacter), changes in the eggshell membrane (Flavobacterium and Serratia), as well as egg white and yolk proteolysis (Proteus) (Corry, 2007).

In the USA, Australia and Japan it is common to wash eggs before they are offered for sale in order to reduce microorganisms on the eggshell surface (Hutchison et al., 2003). At the stage of acquisition eggs are dirty because of the contact with the substrate and feed. Eggshells can be washed. Other treatments may also reduce microorganisms on the eggshell surface and in consequence, the process of egg spoilage can be delayed. These treatments include ionising radiation (Farkas, 1998), UV radiation (Coufal et al., 2003; Rodriguez-Romo and Yousef, 2005; Szablewski et al., 2010a), ozonation (Davies and Breslin, 2003; Rodriguez-Romo and Yousef, 2005) and ultrasound

\footnotetext{
${ }^{*}$ Corresponding author:

Łukasz Tomczyk, Department of Food Quality Management, Poznań University of Life Sciences, ul. Wojska Polskiego 28, 60-625 Poznań,

Poland. Phone: +48 628486 262. E-mail: tomczyk@up.poznan.pl
}

Received: 07 August 2017; $\quad$ Accepted: 31 January 2018 
treatment (Cabeza, 2005). It is important to consider the influence of selected hygienising treatments on eggshell strength. Appropriate eggshell quality guarantees the mechanical safety of eggs, which may be damaged during storage and distribution.

Hydrogen peroxide can be successfully applied to hygienise the egg surface. The method of $\mathrm{H}_{2} \mathrm{O}_{2}$ antimicrobial activity is based on protein oxidation. Simultaneous application of an $\mathrm{H}_{2} \mathrm{O}_{2}$ solution and silver ions may improve the effectiveness of hygienisation by reducing the time of exposure to the preparation on the egg surface (Jung et al., 2008). Therefore, the aim of the study was to determine the influence of different concentrations of silver stabilized hydrogen peroxide on the eggshell strength and microbiological quality.

\section{MATERIAL AND METHODS}

The research material was 490 eggs from Hy-Line White hens kept in cages. The eggs were acquired in the $32^{\text {nd }}$ week of the laying phase. A preparation containing hydrogen peroxide $(50 \%)$ with silver ions $(0.5 \%)$ at different concentrations was used for the analysis. The hygienisation procedure consisted in immersing an egg for 5 minutes in water solutions of the preparation concentrated at $0.01-3 \%$ at a temperature of $10^{\circ} \mathrm{C}$. Analyses were made on the egg laying day and after four weeks of storage. The eggs were dried at a temperature of $15^{\circ} \mathrm{C}$ and transferred to sterile boxes. Then they were stored at a controlled temperature $\left(6 \pm 2^{\circ} \mathrm{C}\right)$ and humidity (65\%), which were applied by means of chilling chamber (Binder KBF 115, Poland). The eggshell strength was assessed by measuring its elastic deformation under pressures of $0.05 \mathrm{~kg}, 1.00 \mathrm{~kg}$ and $1.50 \mathrm{~kg}$, which were applied by means of a manual apparatus (N.V. Marius, Poland). In the next stage of the study, having excluded high concentrations, i.e. 0.9-3\%, the experiment was repeated. The investigations were extended by microbiological analysis, which involved measurements of the total count of aerobic bacteria, bacteria of the Pseudomonas genus and Enterobacteriaceae family, yeasts and moulds by means of the pour-plate method. The microbiological analyses were carried by International Organization for Standardization (ISO) reference methods (according to the Polish Standard of PN-ISO). Analyses of eggshell strength and microbiological analysis were conducted on the egg-laying day and on the $7^{\text {th }}, 14^{\text {th }}$, $21^{\text {st }}$ and $28^{\text {th }}$ day of storage. For microbiological analysis of eggshells, the surface of the 3 eggs was considered a sample. Each group of 3 eggs was kept in in contact witch $90 \mathrm{ml}$ of buffered peptone water for $10 \mathrm{~min}$. The broth was transferred to a dilution serie. The solution was spread on Nutrient Agar, Agar with Cetrimide, Fucidin and Cephaloridine (BTL, Lodz, Poland), Agar with Crystal Violet, Neutral Red, Bile and Glucose (BTL, Lodz, Poland) and Agar with Dichloran, Rose Bengal and Chloramphenicol (BTL, Lodz, Poland). Duplicates were made for all plates. The plates were incubated for 24-48 hours at $30{ }^{\circ} \mathrm{C}$, except for the agar with crystal violet, neutral red, bile and glucose which was incubated at $42^{\circ} \mathrm{C}$. The swabs were spread on the same kind of plates as the eggs. The eggshell strength and microbiological analysis were analyzed using means of a linear function of the regression including the interaction of concentrations (0-3 \%), eggshell strength (0.05 kg, $1.00 \mathrm{~kg}$ and $1.50 \mathrm{~kg})$ and microbiological analysis (count of aerobic bacteria, bacteria of the Pseudomonas genus, Enterobacteriaceae family, yeasts and moulds). All analyses were undertaken using the Statistica 12.5 statistical package.

\section{RESULTS AND DISCUSSION}

Analysis of eggshell strength conducted immediately after treatment with the preparation at low concentrations, i.e. $0.01-3 \%$, did not reveal any significant influence (Fig. 1). After four weeks of storage, the eggshell strength was reduced in the samples hygienised with the preparation at higher concentrations, i.e. 1-3\% (Fig. 2). The changes in elastic deformation may have been caused by the reaction of the silver stabilized hydrogen peroxide with the outer layer of the shell, which is composed almost only of pure calcium carbonate.

The eggshell strength tests were repeated with the preparation at lower concentrations, i.e. 0.01-0.9\%. They confirmed that the concentrations of silver stabilized hydrogen peroxide applied did not have a statistically significant influence on the control samples immediately after treatment or after 4 weeks of storage (Fig. 3). As eggs undergo numerous treatments during acquisition, storage and distribution, it is necessary for the eggshell to be strong and elastic. Studies revealed that the choice of an appropriate breeding system of egg-laying hens and the method of egg sorting and packaging were critical elements for guaranteeing undamaged shells (Mertens et al., 2006). Batkowska and Brodacki (2014) observed in their study, the eggshell was more resistant to damage when eggs were washed by immersion in water at a temperature of $10-21^{\circ} \mathrm{C}$. Their research revealed that the faster diffusion of steam from the egg content made the eggshell more elastic. On the other hand, treatment with sodium hypochlorite containing free chlorine had a negative influence on the outer eggshell structure. At the same time, the research revealed that chemicals may have penetrated into the egg content (Favier et al., 2000). 


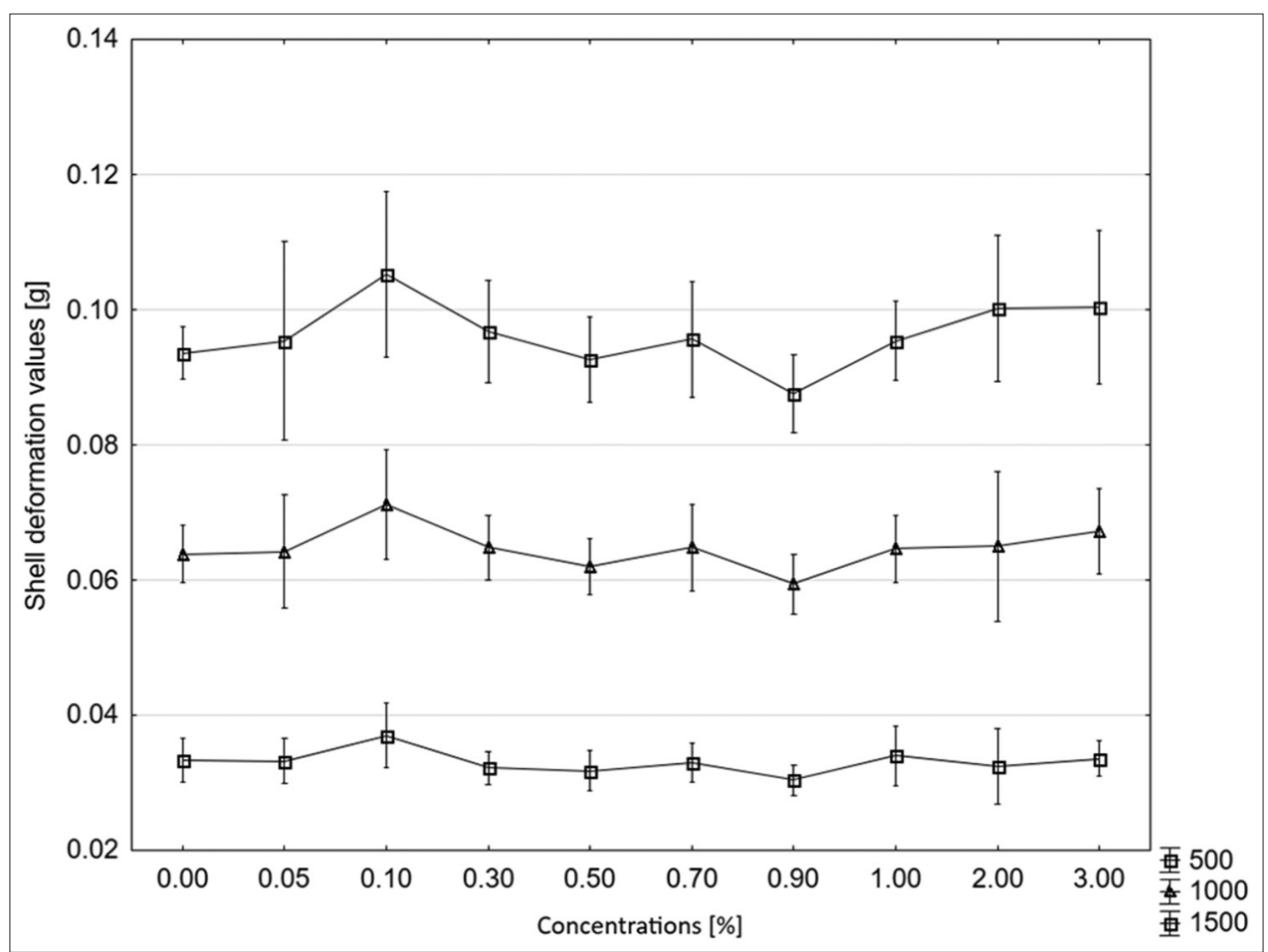

Fig 1. The mean values of elastic deformation of eggshells hygienised with the silver stabilized hydrogen peroxide, $\mathrm{n}=61$.

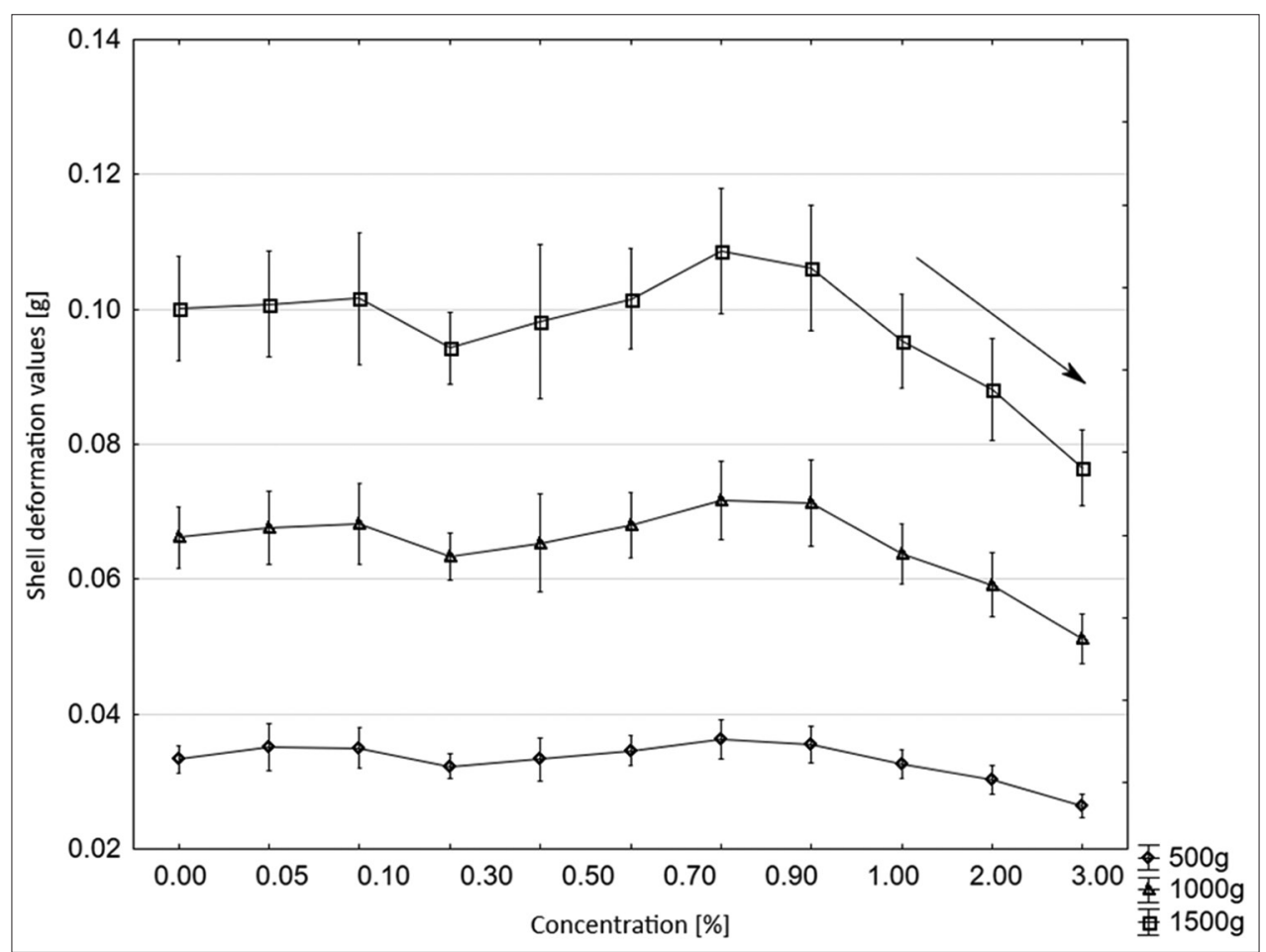

Fig 2. The mean values of elastic deformation of eggshells hygienised with the silver stabilized hydrogen peroxide after 4 weeks of storage, $\mathrm{n}=61$.

The results of the microbiological analysis of the eggshell surface conducted immediately after treatment with the preparation at different concentrations showed that bacteria of the Enterobacteriaceae family, yeasts and moulds were sensitive to it. Egg hygienisation in hydrogen peroxide and silver ions concentrated at $0.1-0.9 \%$ caused complete inactivation of the microorganisms. As a result, they did not proliferate during the four weeks of storage. The study by Padron (1995) gave similar results regarding the influence of $\mathrm{H}_{2} \mathrm{O}_{2}$ on bacteria from the Enterobacteriaceae 


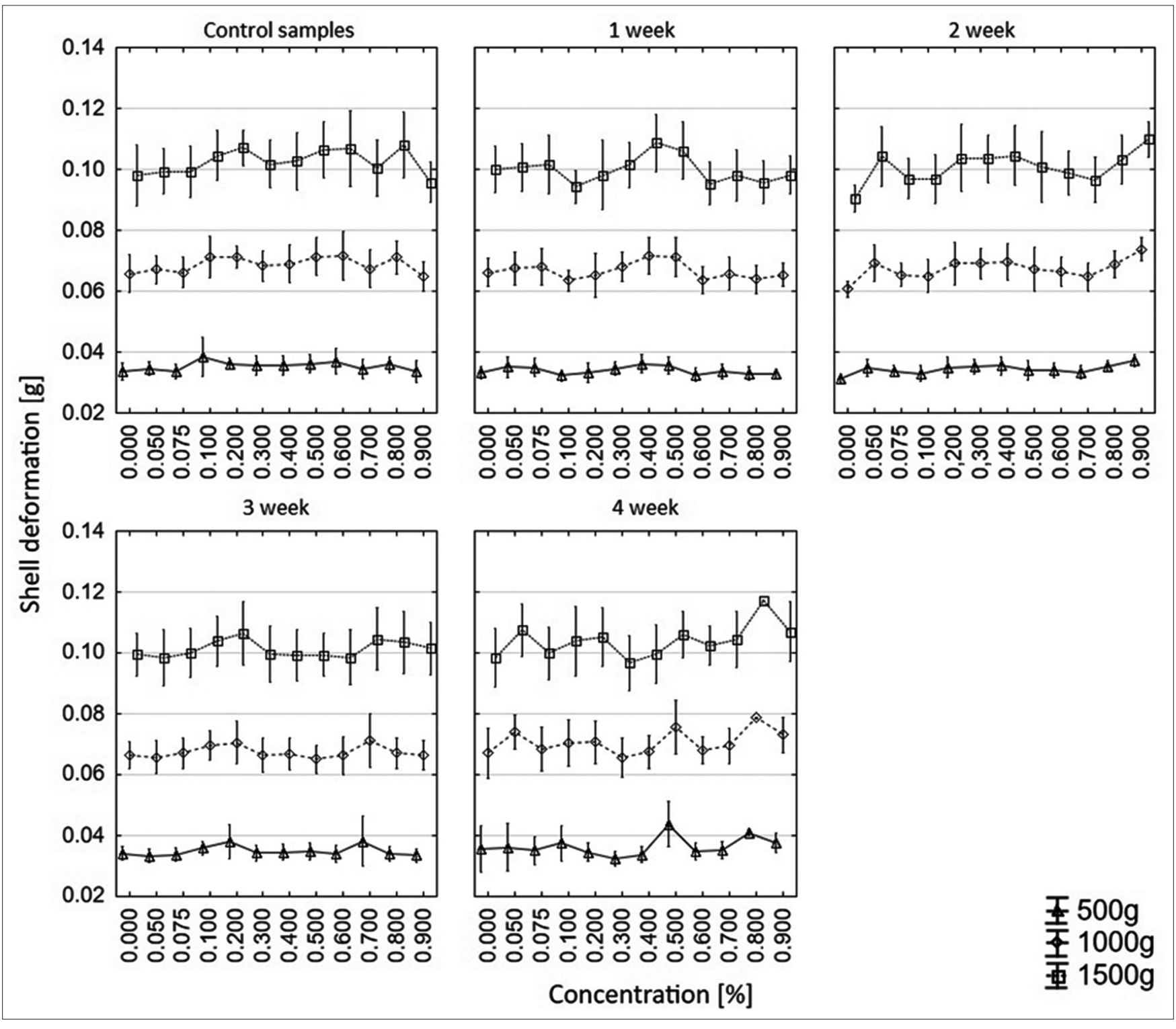

Fig 3. The mean values of elastic deformation of eggshells hygienised with the silver stabilized hydrogen peroxide at different storage periods, $\mathrm{n}=122$.

family, but the bacterial count was reduced by treatment with hydrogen peroxide at a higher concentration $(6 \%)$. The effectiveness of much lower concentrations of the preparation in reducing the bacteria was probably caused by silver ions. Studies showed that silver in the form of ions or nanoparticles had a strong antimicrobial effect (Choi et al., 2008; Rai et al., 2008).

The increase in the concentration of the preparation to $0.03 \%$ also caused statistically significant changes in the count of aerobic bacteria and bacteria of the Pseudomonas genus immediately after treatment. When silver stabilized hydrogen peroxide concentrated at $0.3 \%$ was applied, the count of aerobic bacteria and bacteria of the Psendomonas genus decreased by 1.9 and $0.7 \log \mathrm{CFU} / \mathrm{g}$, respectively (Fig 4). Tukey's test proved that a further increase in the concentration of the preparation to $0.4,0.5,0.6,0.7$, 0.8 and $0.9 \%$ resulted in an insignificant reduction in the count of microorganisms in comparison with eggs hygienised in a $0.3 \%$ silver stabilized hydrogen peroxide. In the study by Sheldon et al. (1991), the bacterial count on the shell of hatching eggs was reduced by $5 \log \mathrm{CFU} / \mathrm{g}$ when a $5 \%$ hydrogen peroxide solution without silver ions was applied.

The influence of the concentration of the preparation and the storage time was assessed by means of a linear function of the regression analysis. The highest concentration of the preparation, i.e. $0.9 \%$, reduced the count of aerobic bacteria and bacteria of the Pseudomonas genus in eggs stored for four weeks under controlled conditions by 1.8 and $1.7 \mathrm{log}$ CFU/g, respectively (Fig 5). 


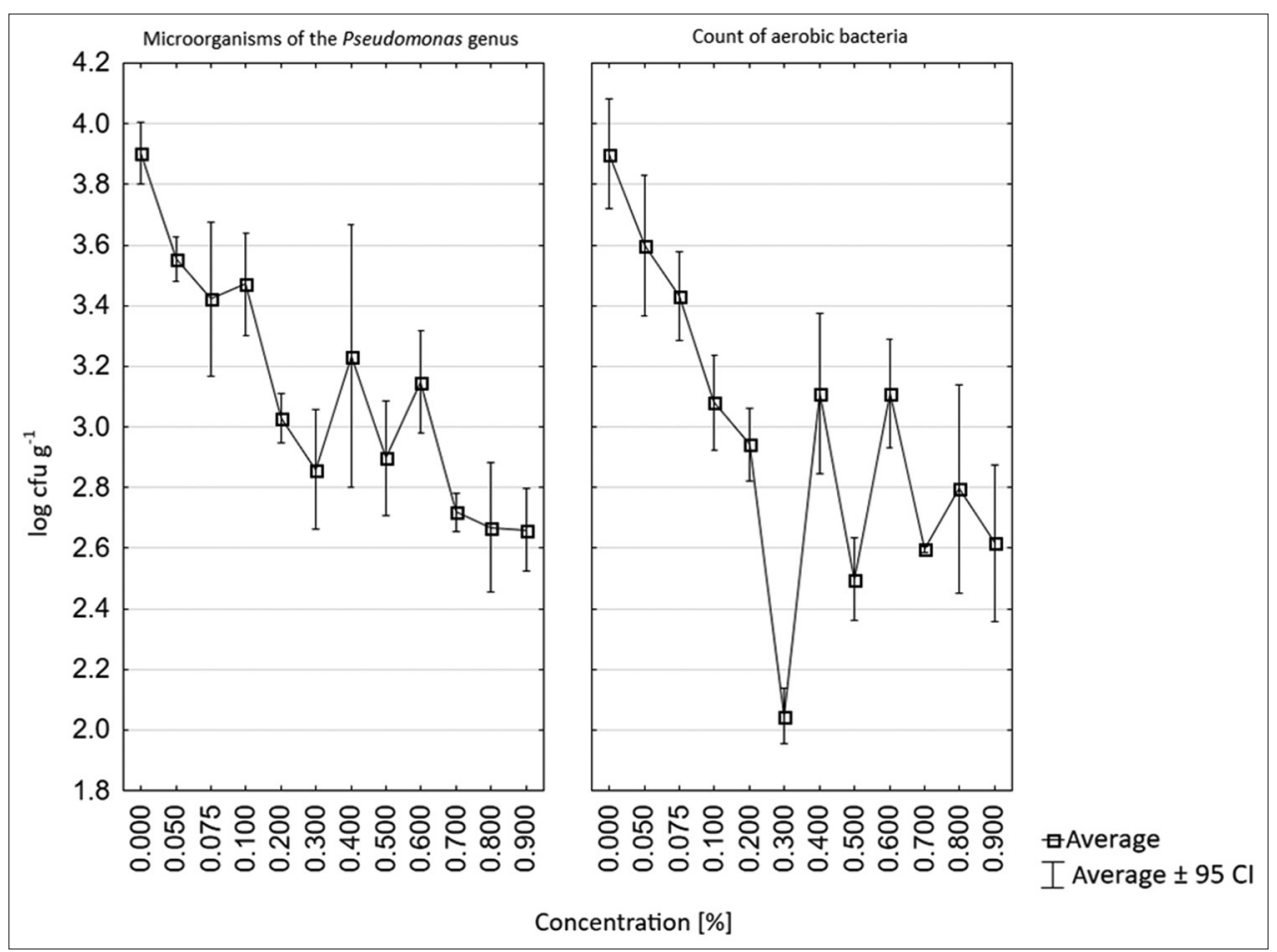

Fig 4. The influence of silver stabilized hydrogen peroxide concentration on the count of bacteria of the Pseudomonas genus and aerobic bacteria, $\mathrm{n}=61$.

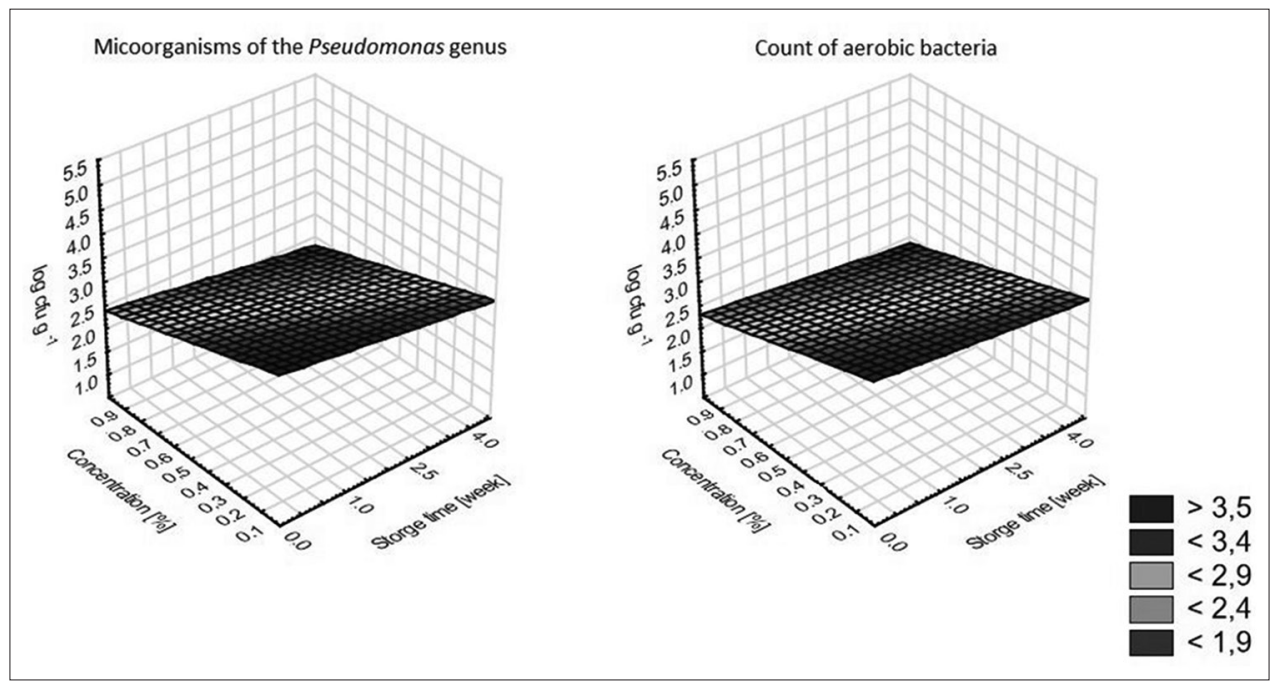

Fig 5. The influence of the concentration of silver stabilized hydrogen peroxide and the storage time on the count of aerobic bacteria and bacteria of the Pseudomonas genus, $\mathrm{n}=245$.

Many studies showed that the effectiveness of treatments applied to eggs also depended on the storage temperature. The storage temperature of washed eggs affected the egg quality to a greater extent than the storage time (Yu-Chi et al., 2016). Washing reduces the temperature inside the egg at a faster rate. This affects the microbiological quality and physiochemical traits of eggs (Caudill et al., 2010). The method of egg hygienisation with silver stabilized hydrogen peroxide at a temperature of $8^{\circ} \mathrm{C}$ significantly reduced the count of microorganisms on the eggshell surface and cooled the egg content quickly.

\section{CONCLUSIONS}

The egg hygienisation treatment with the silver stabilized hydrogen peroxide did not worsen the eggshell strength under the experimental conditions (immersion in solutions concentrated up to $0.9 \%$ for 5 minutes). The best hygienising effect was observed when the solution of the 
silver stabilized hydrogen peroxide was concentrated at $0.3 \%$. It resulted in a significant reduction of the count of selected microorganisms on the eggshell. The hygienising effect was observed both immediately after the treatment and during storage for four weeks. The research findings show that treatment with a silver stabilized hydrogen peroxide under the experimental conditions is a safe procedure because eggshells retain the required mechanical properties and their microbiological cleanness is improved.

\section{Authors' contributions}

Ł.T, R.CR, P.K and T.Sz designed and directed the project; L.T and L.L performed the experiments, R.CR developed the theoretical framework; $\ell . T$ and R.CR wrote the article.

\section{REFERENCES}

Baron, F., M. F. Cochet, N. Grosset, M. N. Madec, R. Briandet, S. Dessaigne, S. Chevalier, M. Gautier and S. Jan. 2007. Isolation and characterization of a psychrotolerant toxin producer, Bacillus weihenstephanensis, in liquid egg products. J. Food Prot. 70(12): 2782-2791.

Batkowska, J. and A. Brodacki. 2014. Wpływ mycia skorupy na wybrane cechy jakości jaj kurzych w czasie przechowywania. Zywn Nauk Technol. Ja. 93: 204-213.

Cabeza, C. M., M. M. García, L. Hoz and I. Cambero. 2005. Thermoultrasonication eliminates salmonellae from intact eggshells without changing the functional properties of their components. J. Food Sci. 70(6): m292-m295.

Caudill, A. B., P. A. Curtis, K. E. Anderson, L. K. Kerth, O. Oyarazabal, D. R. Jones and M. T. Musgrove. 2010. The effects of commercial cool water washing of shell eggs on Haugh unit, vitelline membrane strength, aerobic microorganisms, and fungi. Poult Sci. 89(1): 160-168.

Choi, O., K. K. Deng, N. J. Kim, L. Jr., Ross, R. Y, Surampalli, Z. Hu. 2008. The inhibitory effects of silver nanoparticles, silver ions, and silver chloride colloids on microbial growth. Water Res. 42(12): 3066-3074.

Coufal, C. D., C. Chavez, K. D. Knape and J. B. Carey. 2003. Evaluation of a method of ultraviolet light sanitation of broiler hatching eggs. Poult Sci. 82(5): 754-759.

Corry, J. E. L. 2007. Microbiological analysis of eggs and egg products. W: Microbiological analysis of red meat, poultry and eggs. In: Red. G. C. M., (Ed.), CRC Press, Cambridge England, pp. 182-187.

Davies, R. H. and M. Breslin. 2003. Investigations into possible alternative decontamination methods for Salmonella enteritidis on the surface of table eggs. J. Vet. Med. B Infect. Dis. Vet. Public Health. 50(1): 38-41.

Farkas, J. 1998. Irradiation as a method for decontaminating food. A review. Int. J. Food Microbiol. 44(3): 189-204.

Favier, G. I., M. E. Escudero, L. Velázquez and A. M. De Guzmán. 2000. Reduction of Yersinia enterocolitica and mesophilic aerobic bacteria in egg-shell by washing with surfactants and their effect on the shell microstructure. Food Microbiol. 17(1): 73-81.

Hutchison, M., J. Gittins, A. Walker and A. Moore. 2003. Washing table eggs: A review of the scientific and engineering issues. Worlds Poult Sci. J. 59(2): 233-248.

Jung, W. K., H. C. Koo, K. W. Kim, S. Shin, S. H. Kim and Y. H. Park. 2008. Antibacterial activity and mechanism of action of the silver ion in Staphylococcus aureus and Escherichia coli. Appl. Environ. Microbiol. 74(7): 2171-2178.

Mertens, K., F. Bamelis, B. Kemps, B. Kamers, E. Verhoelst, B. D. Ketelaere, M. Bain, E. Decuypere and J. De Baerdemaeker. 2006. Monitoring of eggshell breakage and eggshell strength in different production chains of consumption eggs. Poult. Sci. 85(9): 1670-1677.

Padron, M. 1995. Egg dipping in hydrogen peroxide solution to eliminate Salmonella typhimurium from eggshell membranes. Avian Dis. 39(3): 627-630.

Rai, M., A. Yadav and A. Gade. 2008. Silver nanoparticles as a new generation of antimicrobials. Biotechnol. Adv. 27(1): 76-83.

Rodriguez-Romo, L. A. and Yousef A.E. 2005. Inactivation of Salmonella enterica serovar enteritidis on shell eggs by ozone and UV radiation. J Food Prot. 68(4): 711-717.

Sheldon, B. W. and J. Brake. 1991. Hydrogen peroxide as an alternative hatching egg disinfectant. Poult Sci. 70(5): 1092-1098.

Szablewski, T., J. Kijowski, R. Cegielska-Radziejewska, A. Dziedzic and A. Kamińska. 2010a. Wpływ promieniowania UV na stan mikrobiologiczny skorupy oraz jakość treści jaj. Zywn Nauk Technol. JA. 2(63): 40-52.

Szablewski, T., K. Stuper, R. Cegielska-Radziejewska, J. Kijowski and J. Perkowski. 2010b. Ergosterol as an indicator of the presence of microscopic fungi in eggs for human consumption produced in different husbandry systems. Poult Sci. 89(11): 2491-2493.

Yu-Chi, L., C. Ter-Hsin, W. Ying-Chen, L. Yi-Chain and T. Fa-Jui. 2016. Effects of egg washing and storage temperature on the quality of eggshell cuticle and eggs. Food Chem. 211: 687-693. 